\title{
BARLEY POWDERY MILDEW “INVERTASE” IS AN ALPHA-GLUCOSIDASE
}

\author{
by \\ IAIN A. DONALDSON ${ }^{1 / *}$ and J. HELMS JØRGENSEN ${ }^{2)}$ \\ 1) Department of Chemistry, Carlsberg Laboratory, \\ Gamle Carlsberg Vej 10, DK-2500 Copenhagen Valby \\ ${ }^{2)}$ Agricultural Research Department, Risø National Laboratory, \\ DK-4000 Roskilde, Denmark \\ ") present address: Department of Biochemistry, University of Oxford, \\ South Parks Road, Oxford OX1 3QU, England
}

\begin{abstract}
Keywords: Sucrose-hydrolase, sucrose, $\beta$-D-fructofuranoside, $\alpha$-D-glucoside, gas-chromatography, mass-spectrometry, high pressure liquid chromatography, fast protein liquid chromatography, Erysiphe graminis hordei
\end{abstract}

Extracts from barley powdery mildew (Erysiphe graminis hordeii) were found to contain sucrose-hydrolase and $\alpha$-glucosidase activities with identical pH optima. When fractionated by anion-exchange and size exclusion chromatography, these extracts showed coincidence of the two enzyme activities in the fractions obtained. Experiments were performed in which sucrose was hydrolysed in the presence of $\mathrm{H}_{2}{ }^{18} \mathrm{O}$ by yeast invertase (E.C. 3.2.1.26), yeast $\alpha$-glucosidase (E.C. 3.2.1.20), and by an extract from the mycelium of barley powdery mildew. Using $\mathrm{GC} / \mathrm{MS}$, the distribution of ${ }^{18} \mathrm{O}$ between derivatives of the hexose products of each reaction was determined. From a comparison of the results, it is concluded that the hydrolysis of sucrose by the powdery mildew extract was catalysed by an $\alpha$-glucosidase.

\section{INTRODUCTION}

The powdery mildews are an economically important group of obligate biotrophic fungal parasites of higher plants (17). The mycelium of these fungi grows on the aerial surfaces of their hosts and can be collected for biochemical analysis.
There is a current belief that sucrose is taken up intact into powdery mildews and hydrolysed within their mycelium. An important component of the evidence supporting this view is the observation that crude extracts from mycelium of pea powdery mildew (Erysiphe pisi) hydrolyse sucrose, with the inference being drawn that

Abbreviations: DTT = dithiothreitol; EPPS = N-(2-hydroxyethyl) piperazine N'-3-propane sulphonic acid; FPLC $=$ fast protein liquid chromatography; $\mathrm{GC}=$ gas chromatography; $\mathrm{GC} / \mathrm{MS}=$ gas chromatography/mass spectrometry; HPLC = high pressure liquid chromatography; MES = 2-(N-morpholino) ethane sulphonic acid; MOPS $=3$-(N-morpholino) propane sulphonic acid; NAD = nicotinamide adenine dinucleotide; PNPG = paranitro phenyl $\alpha$-D-glucoside; Tris = tris (hydroxymethyl) amino methane. 
this activity serves a physiological role (13). This interpretation assumes that the enzyme responsible displays strict specificity for sucrose, and indeed the name "invertase" has been adopted.

"Invertase" is a trivial name for $\beta$-D-fructofuranoside fructohydrolase (E.C. 3.2.1.26) the natural substrate for which is normally sucrose, although it will also slowly hydrolyse raffinose (19). Sucrose is both a $\beta$-D-fructofuranoside and an $\alpha$-D-glucoside, and, therefore, is not only a substrate for invertase (E.C. 3.2.1.26), but can also be hydrolysed by several $\alpha$-glucosidases (E.C. 3.2.1.20) of rather broad substrate specificity $(10,11,18)$. The mechanisms of hydrolysis of sucrose by the two types of enzyme are distinguishable by their splitting of the disaccharide on opposite sides of the glycosidic oxygen atom. The incorporation of ${ }^{18} \mathrm{O}$ from $\mathrm{H}_{2}^{18} \mathrm{O}$ into fructose formed by hydrolysis of sucrose with yeast invertase has been demonstrated by KOSHLAND and STEIN (12), although we are not aware of this approach having been applied to investigate the hydrolysis of sucrose by an $\alpha$-glucosidase.

DONALDSON (4) found that a mycelial extract from E. pisi contained $\alpha$-glucosidase, and concluded that the kinetics of hydrolysis of PNPG and sucrose when both substrates were supplied together were consistent with both activities being catalysed by a single enzyme. We have found that mycelial extracts from barley powdery mildew, E. graminis f.sp. hordeii, also contain $\alpha$-glucosidase and sucrose-hydrolase activities. We have partially purified such extracts in an attempt to separate the two activities by fractional ammonium sulphate precipitation, size exclusion HPLC, and anion-exchange FPLC. We also report a further investigation which elucidates the mechanism by which this extract hydrolyses sucrose.

\section{MATERIALS AND METHODS}

$\left({ }^{18} \mathrm{O}\right.$ )water (WOW 418$) 21$ atom \% was obtained from Amersham International plc, Amersham, Bucks, England. Yeast a-glucosidase (type III $\left(\mathrm{NH}_{4}\right)_{2} \mathrm{SO}_{4}$ precipitate $100 \mathrm{U} / \mathrm{mg}$ protein), yeast invertase (grade VII, lyophilized powder, $825 \mathrm{U} / \mathrm{mg}$ protein), PNPG, and DTT were ontained from Sigma, Poole, Dorset, UK.
Sodium borodeuteride was supplied by Fluka, Switzerland. The molecular weight marker proteins were from Serva, FRG. Ion-exchange resins were purchased from Biorad-UK, Watford, Hertfordshire, UK. "Glucotest" components were obtained from Merck, Darmstadt, FRG. All other reagents used were of Analar quality and either manufactured by the latter firm or by British Drug Houses, Poole, Dorset, UK.

Spectrophotometric measurements were made on Cary 219 and LKB Ultrospec 4050 spectrophotometers. Anion-exchange chromatography was performed using a Pharmacia FPLC apparatus. A Waters 590 HPLC pump was employed for the size exclusion chromatography. GC/MS analysis was performed using a Hewlett Packard 5996 GC/MS.

Barley powdery mildew, Erysiphe graminis DC.: Fr. f.sp. Em. Marchal, isolate CR3 (14), was cultured on barley, Hordeum vulgare L. variety "Carlsberg II", grown in peat compost under constant fluorescent light at an intensity of 200 $\mu \mathrm{Em}^{-2} \mathrm{~s}^{-1}$ and a temperature of $15^{\circ} \mathrm{C}$. The barley leaves were inoculated 9 days after sowing by shaking powdery mildew conidia from infected plants that, nine days previously, had been inoculated in the same way.

\subsection{Enzyme extraction}

All solutions for the purification were maintained at $4{ }^{\circ} \mathrm{C}$. Seven days after inoculation, (before the full onset of sporulation), mycelium was rubbed off the surface of the leaves between finger and thumb and immediately brushed into $10 \mathrm{ml}$ of extraction buffer, $50 \mathrm{~mm}$ potassium phosphate, $\mathrm{pH} 7.2$, containing $1 \mathrm{~mm}$ DTT. Approximately $200 \mathrm{mg}$ fresh-weight of material was collected and, for the experiments employing $\mathrm{H}_{2}{ }^{18} \mathrm{O}$, this suspension was then frozen by immersion in liquid nitrogen, and stored at -70 ${ }^{\circ} \mathrm{C}$ before being homogenized; for all other preparations the mycelium was homogenized immediately. Homogenization was performed in a motorized Potter homogenizer. The homogenate was centrifuged at $20,000 \mathrm{~g}$ for $1 \mathrm{~h}$, and the supernatant was dialysed overnight against 4.51 of extraction buffer. Most extracts were at this stage frozen in liquid nitrogen and 
stored at $-70^{\circ} \mathrm{C}$. Three such dialysed extracts were pooled, and, employing an Amicon YM10 membrane, ultrafiltered to form fraction $\mathrm{C}$, with a protein concentration of about $2 \mathrm{mg} / \mathrm{ml}$. Solid ammonium sulphate was added to $50 \%$ saturation, stirred for $30 \mathrm{~min}$ and the suspension was centrifuged at $10,000 \mathrm{~g}$ for $15 \mathrm{~min}$. The resulting pellet was resuspended in $500 \mu \mathrm{l}$ of extraction buffer to give fraction P1, and the supernatant (S1) was taken to $80 \%$ saturation with solid ammonium sulphate, stirred and centrifuged as before. The resulting pellet was resuspended in $500 \mu \mathrm{l}$ extraction buffer to give fraction P2.

\subsection{Anion-exchange FPLC}

We chose a concentration gradient of orthophosphate as a convenient method of elution for anion exchange chromatography of a-glucosidase (15), because the cationic buffer usually used in combination with a chloride gradient is Tris, which is a powerful inhibitor of this and many other glycohydrolases (8). No alternative cationic buffer was satisfactory for our purposes, because they all absorb at the wavelengths used to detect the very small amounts of protein used in this study.

A $175 \mu$ l sample of $P 2$ which had been dialysed against starting buffer, $10 \mathrm{~mm}$ potassium phosphate $\mathrm{pH} 7.5$, was injected on to a Pharmacia Mono Q HR5/5 column equilibrated with the same buffer, and immediately eluted with a $20 \mathrm{ml}$ linear gradient of limit buffer, 200 $\mathrm{mM}$ potassium phosphate $\mathrm{pH} 7.5$, applied at a flow rate of $1 \mathrm{ml} / \mathrm{min}$. Fractions of $500 \mu \mathrm{l}$ were collected. $25 \mu \mathrm{l}$ aliquots were used for $\alpha$-glucosidase assays and $125 \mu \mathrm{l}$ for sucrose hydrolysis assays.

\subsection{Size-exclusion HPLC}

A $200 \mu 1$ sample of dialysed $P 2$ was injected on to an LKB TSK 3000 SW column, equilibrated with $50 \mathrm{~mm}$ sodium phosphate $\mathrm{pH} 6.8$ containing $100 \mathrm{~mm}$ sodium sulphate, and immediately eluted with the same buffer at a flow rate of $1 \mathrm{ml} / \mathrm{min}$. Fractions of $500 \mu \mathrm{l}$ were collected. $5 \mu \mathrm{l}$ aliquots used for $\alpha$-glucosidase assays and $25 \mu \mathrm{l}$ for sucrose hydrolysis assays.

In order to calibrate the column, the elution volumes for the following molecular weight markers were determined; ferritin, catalase, aldolase, bovine serum albumin, ovalbumin, chymotrypsin A, myoglobin, and cytochrome- $c$.

\section{4. $\alpha$-Glucosidase assays}

The assay is a modification of that introduced by HALVORSON and Ellias (6). The following assay mixture was incubated at $30^{\circ} \mathrm{C}$ for $5 \mathrm{~min}$, $50 \mu \mathrm{l} 30 \mathrm{~mm}$ DTT, $750 \mu \mathrm{l} 120 \mathrm{~mm}$ potassium phosphate pH 7.2, 10 to $350 \mu$ l fraction containing enzyme, and sufficient extraction buffer to bring the volume to $1.45 \mathrm{ml}$. The reaction was initiated by the addition of $50 \mu 133.2 \mathrm{mM}$ PNPG, equilibrated to $30^{\circ} \mathrm{C}$, and the progress of the reaction monitored by continuous measurement of the increase in absorbance at $400 \mathrm{~nm}$.

Owing to the $\mathrm{pH}$-dependence of the absorbance of $\mathrm{p}$-nitrophenol, the optimum $\mathrm{pH}$ for $\alpha$-glucosidase activity was determined using a discontinuous assay method. The assay buffer comprised a mixture of MES, MOPS, and EPPS, each at a concentration of $50 \mathrm{~mm}$, and the ionic strength was maintained at 0.15 by the addition of appropriate amounts of potassium chloride prior to adjustment of the $\mathrm{pH}$ with potassium hydroxide (5). The following assay mixture was incubated at $30^{\circ} \mathrm{C}$ for $5 \mathrm{~min}, 450$ $\mu l$ of buffer, $25 \mu$ l, 30 mM DTT, $25 \mu$ dialysed $\mathrm{P} 2$, and $225 \mu$ l water. The reaction was initiated by the addition of $25 \mu \mathrm{l}$ of $33 \mathrm{~mm}$ PNPG. Six $100 \mu \mathrm{l}$ samples were consecutively taken at five minute intervals, and each added to $900 \mu \mathrm{l}$ of $110 \mathrm{~mm}$ sodium carbonate. The absorbance of these samples at $400 \mathrm{~nm}$ was measured against a reference cell containing all the components of the assay mixture except dialysed $\mathrm{P} 2$, which was replaced with $50 \mathrm{~mm}$ potassium phosphate $\mathrm{pH}$ 7.2 .

\subsection{Sucrose-hydrolase assay}

The following assay mixture was incubated at $30{ }^{\circ} \mathrm{C}$ for $5 \mathrm{~min}, 50 \mu \mathrm{l} 30 \mathrm{~mm}$ DTT, $450 \mu \mathrm{l} 120$ $\mathrm{mM}$ potassium phosphate $\mathrm{pH} 7.2,5$ to $150 \mu \mathrm{l}$ fraction containing enzyme, and sufficient extraction buffer to bring the volume to $750 \mu$ l. The reaction was initiated by the addition of 750 Hl $1.0 \mathrm{M}$ sucrose, equilibrated to $30^{\circ} \mathrm{C}$. Five 200 
$\mu \mathrm{l}$ samples were consecutively taken at $30 \mathrm{~min}$ intervals and each quenched with $40 \mu 13.0 \mathrm{M}$ Tris/ $\mathrm{HCl} \mathrm{pH} 7.6$.

The glucose content of each quenched sample was determined by the addition of $1 \mathrm{ml}$ of "Glucotest" reagent comprising, $5.2 \mathrm{kU} / 1$ glucose dehydrogenase $110 \mathrm{U} / 1$ mutarotase, and 1.1 $\mathrm{mMNAD}$, in $120 \mathrm{~mm}$ potassium phosphate $/ 150$ mM sodium chloride, $\mathrm{pH} 7.6$ (1). The samples were then incubated at $25^{\circ} \mathrm{C}$ for $30 \mathrm{~min}$ and the absorbance at $340 \mathrm{~nm}$ measured against a reference cell containing all the components of the assay mixture except dialysed $\mathrm{P} 2$, which was replaced with $50 \mathrm{~mm}$ potassium phosphate $\mathrm{pH}$ 7.2.

For the determination of the optimum $\mathrm{pH}$, the MES/MOPS/EPPS buffers described above were used. The following assay mixture was incubated at $30^{\circ} \mathrm{C}$ for $5 \mathrm{~min}, 75 \mu \mathrm{l} 30 \mathrm{~mm}$ DTT, $900 \mu \mathrm{l}$ buffer, and $25 \mu \mathrm{l}$ dialysed P2. The reaction was initiated by the addition of $1 \mathrm{ml}$ of $1.0 \mathrm{M}$ sucrose. Five $100 \mu \mathrm{l}$ samples were consecutively taken at $10 \mathrm{~min}$ intervals, and each was quenched with $20 \mu \mathrm{l} 3.0 \mathrm{M}$ Tris/ $\mathrm{HCl}$ buffer described above. The glucose content of each quenched sample was determined by the addition of $880 \mu \mathrm{l}$ "Glucotest" reagent, and the assay performed as described above.

Protein was measured by the method of KALB and BERNLOHR (9).

\subsection{Hydrolysis of sucrose in the presence of $\mathrm{H}_{2}{ }^{18} \mathrm{O}$}

Enzyme solutions employed were as follows. Yeast invertase $350 \mu \mathrm{g} / \mathrm{ml}$ was dissolved in 10 mM sodium acetate/acetic acid, $\mathrm{pH}$ 5.0. A sample $(10 \mu \mathrm{l})$ of yeast $\alpha$-glucosidase suspension was dissolved in $40 \mu \mathrm{l}$ of $6 \mathrm{~mm}$ potassium phosphate $\mathrm{pH}$ 6.8. The powdery mildew enzyme fraction used was $\mathbf{P} 2$ dialysed against extraction buffer.

Aliquots $(500 \mu \mathrm{l})$ of the following reaction mixtures were each freeze-dried in Eppendorf centrifuge tubes in a Savant "Speedvac concentrator"; a. (For yeast invertase) $5 \mathrm{~mm}$ sodium citrate/citric acid, pH 5.0,500 $\mu \mathrm{M}$ sucrose. b. (For yeast $\alpha$-glucosidase) $6 \mathrm{~mm}$ potassium phosphate, pH 6.8, $500 \mu \mathrm{m}$ sucrose, $1 \mathrm{~mm}$ DTT. c. (For dialysed P2) $6 \mathrm{~mm}$ potassium phosphate, pH 7.2, $500 \mu \mathrm{M}$ sucrose, $1 \mathrm{~mm}$ DTT. To each dried mixture $40 \mu \mathrm{l}$ of water enriched with $\mathrm{H}_{2}{ }^{18} \mathrm{O}$ were added. Reactions were initiated by the addition of $10 \mu \mathrm{l}$ of enzyme solution, and incubated at $25^{\circ} \mathrm{C}$ for $3 \mathrm{~h}$.

\subsection{Preparation of derivatives for GC/MS}

The hexose products in the hydrolysates were reduced and acetylated for GC/MS analysis. Each of the enzymatic reaction mixtures was passed through small columns of $\mathrm{AG} 50\left(\mathrm{H}^{+}\right)$and AG3 $\left(\mathrm{OH}^{-}\right)$ion exchange resins, with binding capacities in five fold excess over the ions in the sample. The eluates were dried under reduced pressure at $35^{\circ} \mathrm{C}$, redissolved in $200 \mu$ of 10 $\mathrm{mg} / \mathrm{ml}$-sodium borodeuteride solution and incubated at $25^{\circ} \mathrm{C}$ for $3 \mathrm{~h}$. After this period, each of the reaction mixtures was acidified with $50 \mu \mathrm{l}$ of glacial acetic acid. The mixtures were then dried under reduced pressure at $35^{\circ} \mathrm{C}$, and each washed with $300 \mu 1 \quad 1 \% \mathrm{v} / \mathrm{v}$-acetic acid in methanol and then dried in the same way. This washing and drying was repeated five times, then the reactants were dried, and acetylated by the addition of $250 \mu \mathrm{l}$ of acetic anhydride and incubation at $100{ }^{\circ} \mathrm{C}$ for $3 \mathrm{~h}$. The excess acetic anhydride was removed at $35^{\circ} \mathrm{C}$ under reduced pressure. To each tube, $500 \mu \mathrm{l}$ of dichloromethane and $1 \mathrm{ml}$ of water were added, and the tubes were vortex mixed. The lower phase of each vessel was collected, dried down under a stream of nitrogen, and taken up in $20 \mu \mathrm{l}$ of dichloromethane.

\subsection{GC/MS}

The reduced acetylated derivatives were separated on a Supelcowax 10 bonded-phase capillary column $(25 \mathrm{~m} \times 320 \mu \mathrm{l})$ using an "oncolumn" injector, and a flow rate of helium of $3 \mathrm{ml} / \mathrm{min}$. The temperature gradient was $100^{\circ} \mathrm{C}$ (held for $2 \mathrm{~min}$ ) to $240{ }^{\circ} \mathrm{C}$ (held for $15 \mathrm{~min}$ ) at $10^{\circ} \mathrm{C} / \mathrm{min}$. Mass spectral data were recorded using electron impact ionization $(700 \mathrm{~V})$ with a source temperature of $150^{\circ} \mathrm{C}$ and a pressure of $2.66 \times 10^{-3} \mathrm{~Pa}$. Selective ion monitoring was performed with windows set between $\mathrm{m} / \mathrm{z} 216.7$ 217.7, and $\mathrm{m} / \mathrm{z} 219.7-220.7$. The GC/MS interface was held at $280^{\circ} \mathrm{C}$. 


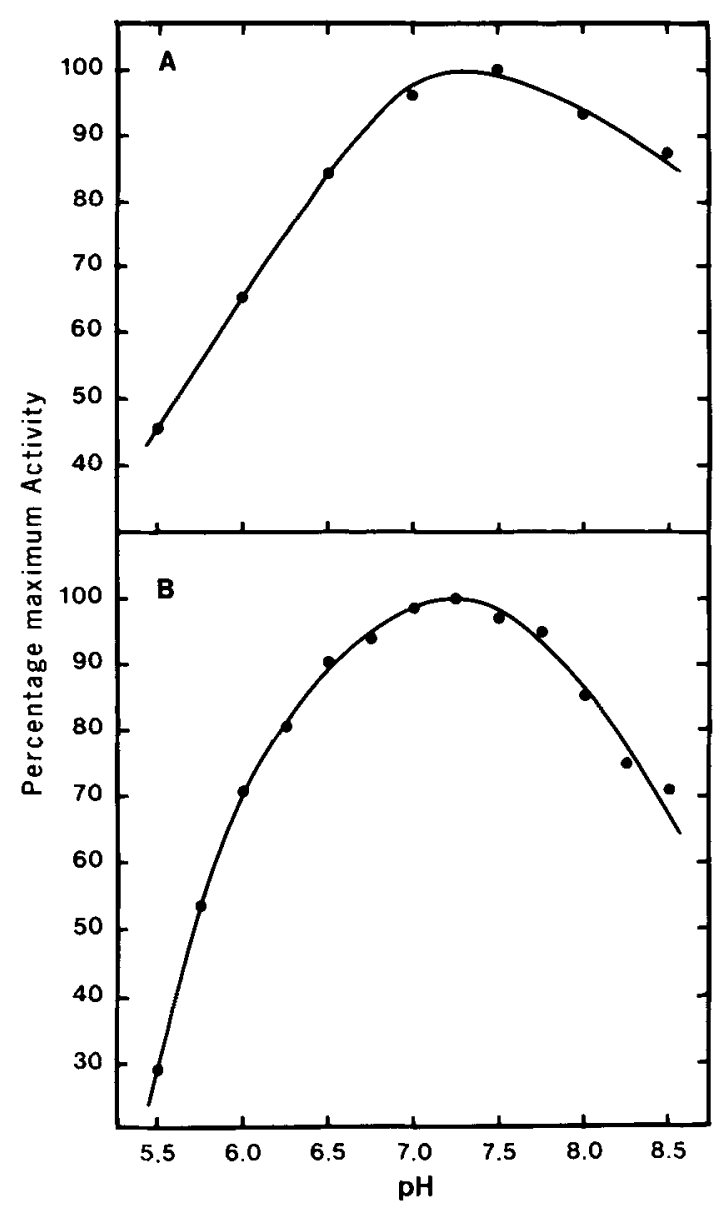

Figure 1. $\mathrm{pH}$ profiles of activities. A, sucrose-hydrolase. $B, \alpha$-glucosidase.

\section{RESULTS}

Separate preparations were used in the chromatographic procedures and measurement of $\mathrm{pH}$ optimum. In all cases the recovery of both activities in the $50-80 \%$ saturation ammonium sulphate step was in excess of $70 \%$ of those found in the crude extract. In agreement with the findings of MANNERS and GAY (13), with E. pisi, no sucrose hydrolase activity could be detected in the pellet of cell debris from $E$. graminis hordeii; $\alpha$-glucosidase activity was, however, consistently detected in this fraction.

Figure 1 shows that the $\mathrm{pH}$ optima for the two activities are identical, although the $\mathrm{pH}$ profiles differ in shape. The use of MES/MOPS/EPPS buffer at half-concentration at $\mathrm{pH} 5.5,7.0$, and

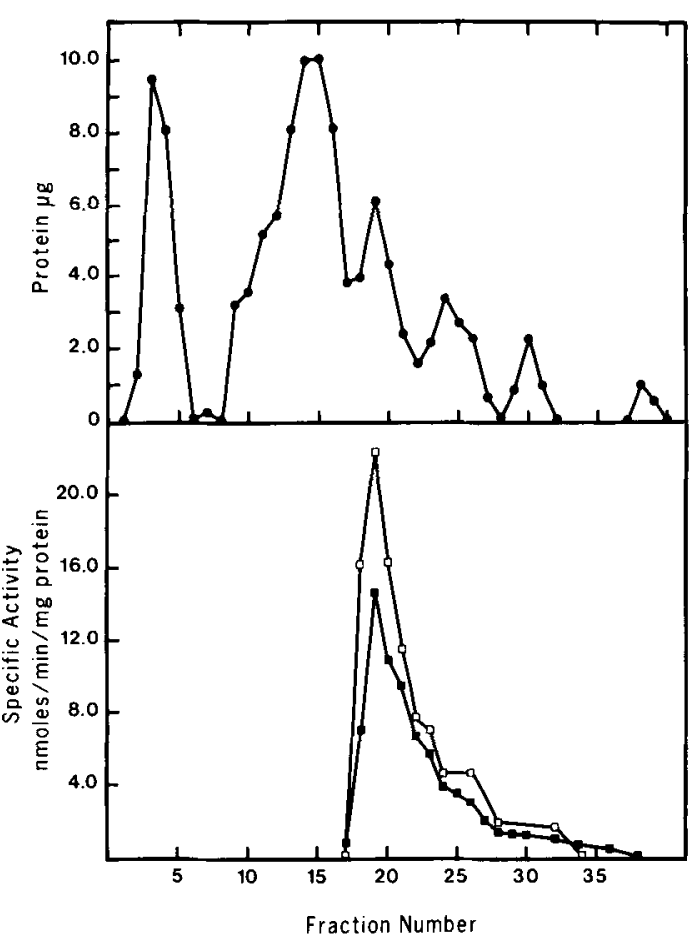

Figure 2. Elution profiles of anion-exchange FPLC. $\bullet$, protein, $\square$, sucrose hydrolase, $\mathbf{\square}, \alpha$-glucosidase.

8.5 did not significantly alter the activities measured, and so it would appear that the assays were free from interference by this buffer.

The elution profiles of sucrose-hydrolase and $\alpha$-glucosidase activities in fractions obtained by anion-exchange chromatography are coincident (Fig. 2). A synchronous elution of $\alpha$-glucosidase and sucrose-hydrolase activities also occurred during size-exclusion chromatography (Fig. 3). Both activities were estimated to elute with proteins of molecular weight 65,000 .

The results of the purification of the barley powdery mildew enzyme for the GC/MS experiment are summarized in Table I. A considerable loss $(-37 \%)$ of sucrose hydrolase activity accompanied the $50-80 \%$-saturation ammonium sulphate precipitation step, but a concomitant increase in PNPG-hydrolase activity $(+52 \%)$ was observed. Neither of the two activities was found in the supernatant $S 2$, so this loss appears not to result simply from a failure to precipitate the enzyme. An effect of ammonium sulphate 


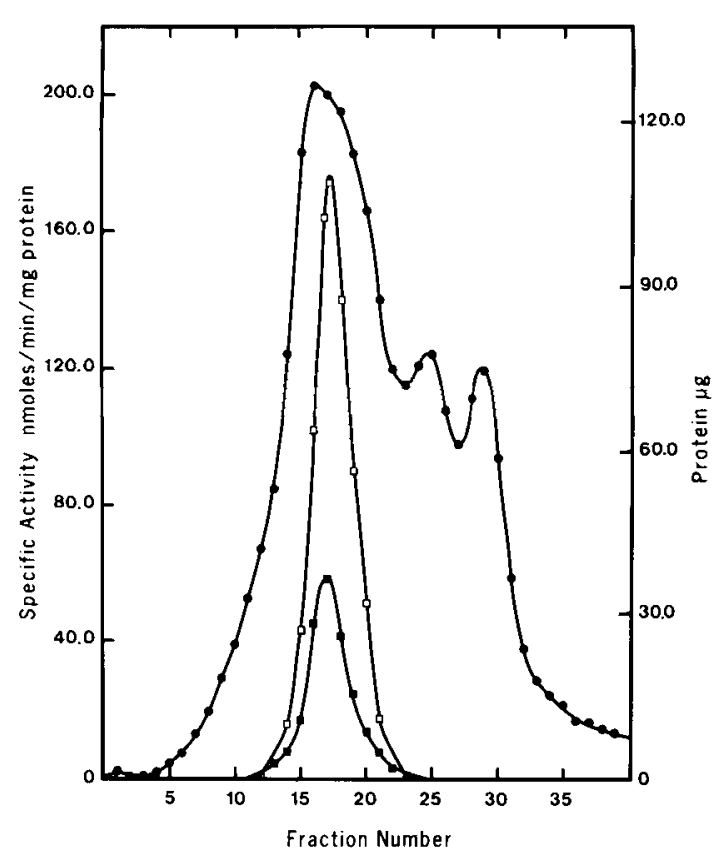

Figure 3. Elution profiles of size-exclusion FPLC. protein, $\square$, sucrose hydrolase, $\mathbf{\square}, \boldsymbol{\alpha}$-glucosidase.

on the assays appears not to be the cause, since ammonium sulphate was present in the assay mixtures of fraction P1 in greater amounts than those for P2, and yet no such inhibitory effect was observed.

In order to prevent the formation of multiple anomers and tautomers, the hexoses prepared for $\mathrm{GC}$ were first reduced to form sugar alcohols before acetylation. The reduction of glucose produces a single product, glucitol. The reduc- tion of fructose, however, occurs at a chiral centre at $\mathrm{C} 2$ and so two products are formed, glucitol and mannitol (Fig. 4). Therefore, when reducing a mixture of the two hexoses, the mannitol formed originates from fructose alone; whereas both glucose and fructose contribute to the formation of glucitol. Glucitol had a retention time of $19.755 \mathrm{~min}$ and mannitol 19.175 min.

The ions selected for detection by mass spectrometry, $\mathrm{m} / \mathrm{z} 220$ (Fig. 5, I, II and III) and $\mathrm{m} / \mathrm{z}$ 217 (Fig. 5, I-VI) result from the fission of the sugar alcohol acetate derivatives between $\mathrm{C} 3$ and $\mathrm{C} 4$. Reduction with sodium borodeuteride ensured molar parity between the abundance of the $\mathrm{m} / \mathrm{z} 217$ ion and the alditol acetates from which it originated. This expedient ensured that, when split between $\mathrm{C} 3$ and $\mathrm{C} 4$, the sugar alcohol derivatives not containing ${ }^{18} \mathrm{O}$ (Figure 5, IV, V and VI) did not form two moles of $\mathrm{m} / \mathrm{z} 217$ per mole, but one mole of $\mathrm{m} / \mathrm{z} 217$ and one of $\mathrm{m} / \mathrm{z}$ 218 . The chromatogram produced by the detection of the $\mathrm{m} / \mathrm{z} 217$ ion therefore serves as a profile of the total molar amount of any derivative eluting at a given retention time.

Figure 6 shows the chromatograms produced by detection of $\mathrm{m} / \mathrm{z} 217$ and $\mathrm{m} / \mathrm{z} 220$ from the sugar alcohol acetate derivatives of the products from the hydrolysis of sucrose by the three enzymes. In the products formed by yeast invertase activity (Figs. 6A and 6B), the greater proportion of the $\mathrm{m} / \mathrm{z} 220$ ion formed from the mannitol derivative (Fig. 6B) is consistent with the incorporation of ${ }^{18} \mathrm{O}$ in the fructosyl side of the sucrose glycosidic bond. In the products of yeast $\alpha$-glucosidase (Figs. 6C and 6D) the pro-

Table I. The distribution of PNPG-and sucrose-hydrolysing activities in fractions obtained by ammonium sulphate precipitation of the extract from barley powdery mildew.

\begin{tabular}{|c|c|c|c|c|c|c|}
\hline \multirow[t]{2}{*}{ Fraction } & \multirow[t]{2}{*}{$\begin{array}{l}\text { Volume } \\
\text { (ml) }\end{array}$} & \multicolumn{2}{|c|}{$\begin{array}{c}\text { Activity } \\
\text { (nmoles/min) }\end{array}$} & \multirow[t]{2}{*}{$\begin{array}{l}\text { Protein } \\
(\mathrm{mg})\end{array}$} & \multicolumn{2}{|c|}{$\begin{array}{c}\text { Specific Activity } \\
\text { (nmoles/min/mg protein) }\end{array}$} \\
\hline & & PNPG & Sucrose & & PNPG & Sucrose \\
\hline $\mathrm{C}$ & 20 & 2244 & 1532 & 34.1 & 65.80 & 44.93 \\
\hline P1 & 0.445 & 275 & 273 & 6.26 & 43.85 & 43.57 \\
\hline S1 & 22.75 & 1427 & 1438 & 18.84 & 75.73 & 76.31 \\
\hline P2 & 0.350 & 2164 & 903 & 3.4 & 636.44 & 265.58 \\
\hline S2 & 0 & 0 & 0 & 14.32 & 0 & 0 \\
\hline
\end{tabular}


<smiles>O=CC(O)C(O)C(O)C(O)CO</smiles>

GLUCOSE
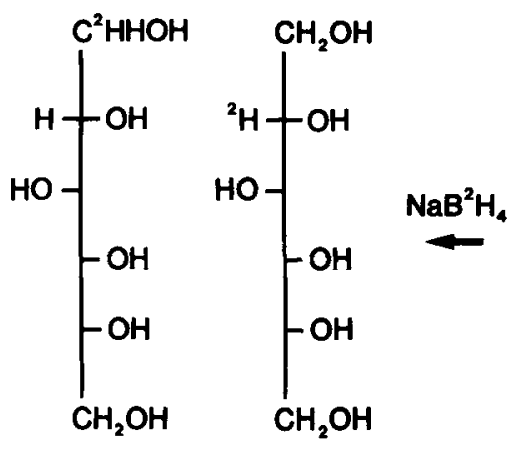

GLUCITOL

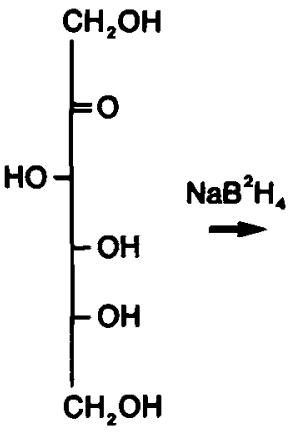

FRUCTOSE

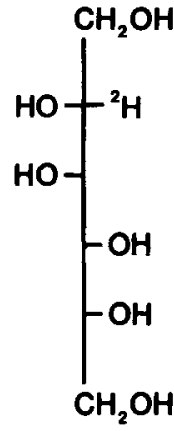

MANNITOL

Figure 4. The reduction of glucose and fructose with sodium borodeuteride.

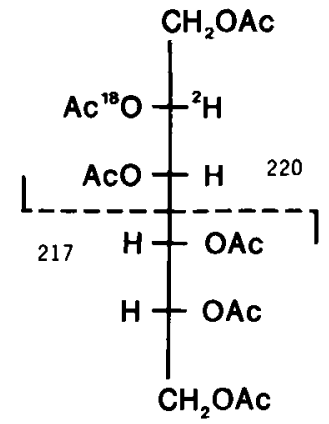

I

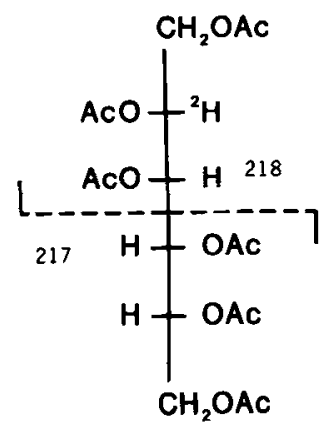

IV

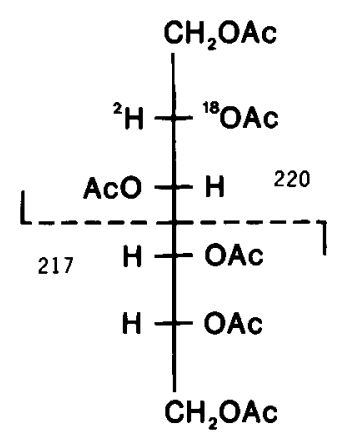

||

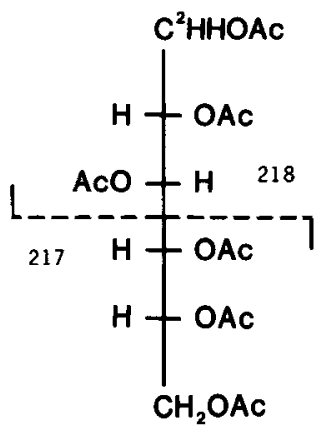

V

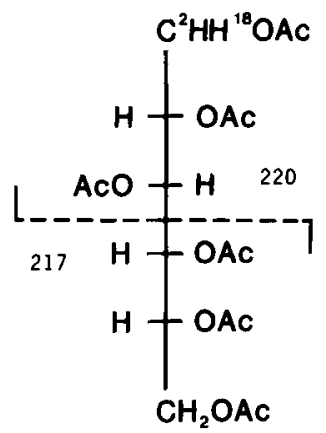

III

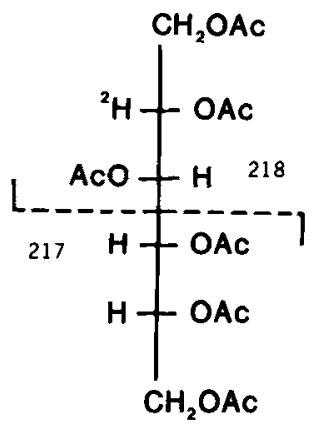

VI

Figure 5. The deuterated, acetylated derivatives of the products of sucrose hydrolysis. $\mathrm{I},{ }^{18} \mathrm{O}$-labelled hexa-acetyl mannitol formed from fructose. II, ${ }^{18} \mathrm{O}$-labelled hexa-acetyl glucitol formed from fructose. III, ${ }^{18} \mathrm{O}$-labelled hexa-acetyl glucitol formed from glucose. IV, Hexa-acetyl mannitol formed from fructose. V, Hexa-acetyl glucitol formed from fructose. VI, Hexa-acetyl glucitol formed from glucose. 


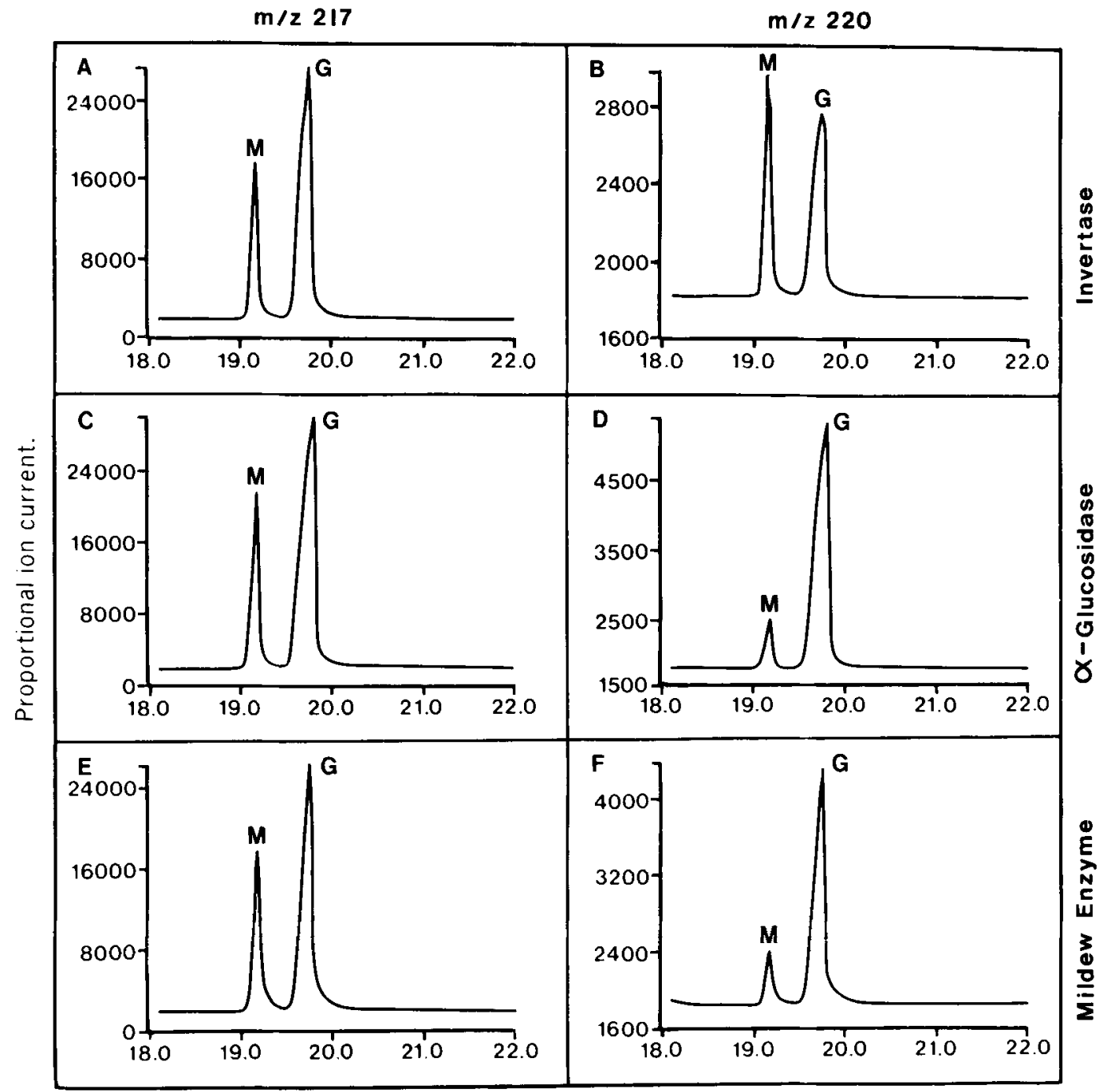

Retention time (mın.)

Figure 6. The distribution of $\mathrm{m} / \mathrm{z} 217$ and $\mathrm{m} / \mathrm{z} 220$ ions in the gas chromatograms of the products from the hydrolysis of sucrose catalysed by different enzymes. A, m/z 217 invertase; $B, \mathrm{~m} / \mathrm{z} 220$ invertase; $C, \mathrm{~m} / \mathrm{z} 217$ yeast $\alpha$-glucosidase; $\mathrm{D}, \mathrm{m} / \mathrm{z} 220$ yeast $\alpha$-glucosidase; $\mathrm{E}, \mathrm{m} / \mathrm{z} 217$ barley powdery mildew extract; $\mathrm{F}, \mathrm{m} / \mathrm{z} 220$ barley powdery mildew extract. M, Hexa-acetyl mannitol; G, Hexa-acetyl glucitol.

portion of the $\mathrm{m} / \mathrm{z} 220$ ion arising from the mannitol derivative is greatly diminished below that of invertase, and this low abundance is consistent with the enzymatic incorporation of ${ }^{18} \mathrm{O}$ being confined to the glucosyl moiety of the sucrose. The distribution of the $\mathrm{m} / \mathrm{z} 220$ ion between the mannitol and glucitol formed from the products of the powdery mildew enzyme extract (Fig. 6F) closely resembles that of the yeast $\alpha$-glucosidase (Fig. 6D), but differs profoundly from that of the yeast invertase (Fig. 6B). We therefore conclude that the powdery mildew enzyme is an $\alpha$-glucosidase. 


\section{DISCUSSION}

The results show that the sucrose-hydrolase and PNPG-hydrolase activities in the extracts from barley powdery mildew are chromatographically inseparable because they are catalysed by a single enzyme which is an $\alpha$-glucosidase (E.C. 3.2.1.20). No trace of sucrose hydrolysis by $\beta$-D-fructofuranosidase (E.C. 3.2.1.26) was detected in the mildew extract.

Analysis of the products formed by the powdery mildew extract in the presence of $\mathrm{H}_{2}{ }^{18} \mathrm{O}$ and sucrose revealed that the proportion of $\mathrm{m} / \mathrm{z}$ 220 in hexa-acetyl mannitol compared with hexa-acetyl glucitol is very slightly greater than that from the yeast $\alpha$-glucosidase (Figs. 6D and $6 \mathrm{~F})$. This small discrepancy is, however, also reflected in the distribution of the $\mathrm{m} / \mathrm{z} 217$ ion between these two derivatives (Figs. $6 \mathrm{C}$ and $6 \mathrm{E}$ ), and we therefore consider it to arise from extra mannitol formed in the reaction mixture of the mildew extract. We believe that this may originate from mannose produced from the hydrolysis of glycoproteins in the mildew extract, which we have found also contains $\alpha$-mannosidase (data not shown).

IsHIZAWA and Miwa (7) showed that, in the presence of methanol and sucrose, yeast invertase produced methyl- $\beta$-D-fructofuranoside amongst its products, whereas yeast $\alpha$-glucosidase formed methyl- $\alpha$-D-glucoside. Under such conditions, the methanol competes with water as a nucleophile, donating to one or the other side of the glycosidic oxygen. Unfortunately, the mechanism of sucrose hydrolysis by the mildew extract was not accessible to investigation in this way because it was found to suffer a total loss of activity in the presence of methanol.

The decrease in sucrose-hydrolase activity and the concomitant increase in PNPG-hydrolase activity as a result of the $50-80 \%$ saturation ammonium sulphate step (Table I) reflect a general tendency for the proportions of these two activities to vary. It is possible that one activity has increased at the expense of the other. Large shifts in the proportions of the two activities were also apparent after chromatography of P2 (Figs. 2 and 3), such that sucrose-hydrolase activity exceeded that of PNPG-hydrolysis. Similar changes in the specificity of a sucrosehydrolysing $a$-glucosidase from honey-bee haemolymph are believed to involve transitions in its Hill coefficient (2).

Any physiological significance of the hydrolysis of sucrose by $\alpha$-glucosidase from barley powdery mildew remains to be elucidated. Some $\alpha$-glucosidases do fulfil a physiological role in the hydrolysis of sucrose, for example, in mammalian gut (11), but it should not be overlooked that glycogenolysis is a major physiological function of $a$-glucosidases in fungi (3). Some strains of yeast which do not possess any of the SUC genes for invertase, but do express maltase (an $\alpha$-glucosidase), will grow on sucrose as a carbon source (B.S. Cox, personal communication). As maltase is a cytoplasmic enzyme, these strains must also be permeable to sucrose in order that it may be hydrolysed by this enzyme. The existence of a sucrose permease in yeast has been proposed (16).

\section{ACKNOWLEDGEMENTS}

IAD was gratefully in receipt of a NATO Science Fellowship and this work was funded by the Carlsberg Foundation. We would like to thank JIANG WEI MING for technical assistance with some of this work, and THOMAS MATTHIASEN for the use of his HPLC apparatus. We are grateful to Prof. RAYMOND DWEK for use of his GC/MS and Dr. Mike FERGUSON for assistance with its operation.

\section{REFERENCES}

1. Banauch, D. von, W. Brümmer, W. Ebeling, H METZ, H. RiNDFREY, H. LANG, K. LEYBOLd \& W RICK: Eine Glucose-Dehydrogenase für die Glucose-Bestimmung in Körperflūssigkeiten. Z. Klin. Chem. Klin. Biochem. 13, 101-107 (1975)

2. Bounias, M. \& M.R.J. Morgan: Adaptation of honeybee haemolymph $\alpha$-glucosidase to changing physiological requirements by transitions in the Hill coefficient. Int. J. Biochem. 16, 939-941 (1984)

3. Colanna, W.J. \& P.T. MageE: Glycogenolytic enzymes in sporulating yeast. J. Bacteriol. 134, 844853 (1978)

4. DonaldSON, I.A.: Erysiphe pisi, a model for fungal/higher plant biotrophic parasitism. D. Phil. Thesis, University of Oxford (1984)

5. ElLiS, K.J. \& J.F. Morrison: Buffers of constant 
ionic strength for studying $\mathrm{pH}$-dependent processes. Meth. Enzymol. 87, 405-426 (1982)

6. HalVorson, H. \& L. Ellias: The purification and properties of an $\alpha$-glucosidase of Saccharomyces italicus Y1225. Biochim. Biophys. Acta 30, 28-40 (1958)

7. ISHIZAWa, K. \& T. MiWa: Enzymic transfer of $\beta$ fructofuranose residue and $\alpha$-glucopyranose residue of sucrose. Symposia on Enzyme Chemistry (Japan) 9, 40-41 (1954)

8. JøRGENSEN, B.B. \& O.B. JøRGENSEN: Inhibition of barley malt $\alpha$-glucosidase by tris (hydroxymethyl) amino methane and erythritol. Biochim. Biophys. Acta 146, 167-172 (1967)

9. KALB, V.F. JR. \& R.W. BERNLOHR: A new spectrophotometric assay for protein in cell extracts. Analyt. Biochem. 82, 362-371 (1977)

10. Khan, N. \& N.R. EATON: Purification and characterization of maltase and $\alpha$-methyl glucosidase from yeast. Biochim. Biophys. Acta 146, 173-180 (1967)

11. Kolinska, J. \& G. Semenza: Studies on intestinal sucrase and on intestinal sugar transport $\mathrm{V}$. Isolation and properties of sucrase-isomaltase from rabbit small intestine. Biochim. Biophys. Acta 146, 181-195 (1967)

12. Koshland, D.E. \& S.S. Stein: Correlation of bond breaking with enzyme specificity. Cleavage point of invertase. J. Biol. Chem. 208, 139-148 (1954)

13. MANNERS, J.M.\&J.L. GAY: Transport translocation and metabolism of ${ }^{14} \mathrm{C}$-photosynthates at the hostparasite interface of Erysiphe pisi. New Phytol.91, 221-244 (1982)

14. Moseman, J.G. \& G.W. Schaller: The effect on various cultures of Erysiphe graminis f.sp. hordei of the gene in barley conditioning resistance to culture CR3. Phytopathology 49, 207-209 (1959)

15. Needleman, R.B., H.J. Federoff, T.R. EccleShall, B. Buchferer \& J. Marmur: Purification and characterization of an $\alpha$-glucosidase from Saccharomyces carlsbergensis. Biochemistry 17, 4657-4661 (1978)

16. Santos, E., R. Rodriguez, M.V. Elorza \& R. SenTANDREU: Uptake of sucrose by Saccharomyces cerevisiae. Arch. Biochem. Biophys. 216, 652-660 (1982)

17. Spencer, D.M. (ed.): In: The Powdery Mildew. Academic Press ed., London (1978)

18. URLaUb, H. \& G. WÖBeR: $\alpha$-Glucosidase, a membrane-bound enzyme of glucan metabolism in Bacillus amyloliquifaciens. Biochim. Biophys. Acta 522, 161-173 (1978)

19. WEBB, E.C. (ed.): In: Enzyme Nomenclature 1984. Academic Press ed., London \& New York

Accepted by S.O. ANDERSEN 